\title{
Growing Together: Advancing Networks for Service-learning Actors in Asia
}

\author{
Wai Ching Angela Wong* \\ United Board for Christian Higher Education in Asia, 1/F Chung Chi College \\ Administration Building, The Chinese University of Hong Kong, Shatin, N. T., Hong Kong
}

\begin{abstract}
This paper traces the history of United Board's engagement with service-learning through higher education in Asia and reflects on the recent discussion about the relevancy of service-learning activities to today's higher education system. Through a close review of the experience shared in recent projects sponsored and organized by United Board in the last five years, service learners from colleges and universities around Asia all testified an process that deepens both cognitive and affective learning, generating in service-learning actors-faculty, students and community members - a connection that could inspire and sustain their vision and passion for life. Despite the seemingly still marginalized status of service learning programs and faculty in most higher education institutions, educators believing in whole person education only find service-learning ever more important in the face of higher education that has been increasingly trapped by the ranking race.
\end{abstract}

Key words: Campus-community engagement, cognitive and affective learning, cross border learning, education of the heart, united board

\section{Introduction}

United Board for Christian Higher Education in Asia is going to celebrate its centennial in 2022. Several missionary boards running colleges and universities in China since the 19th century united into an associated board (later renamed the United Board) for more effective use of human and financial resources in 1922. Two of the earliest Chinese universities set up in 1888 include the North China College and Teng Chow College, which evolved over time to become Peking University and Shantung University respectively. When United Board's work had to leave China in 1952, it left behind 13 well established colleges and universities in different parts of China with Christian heritages. Its work then expanded beyond China to Northeast Asia to Hong Kong, Taiwan, Korea and Japan, to Southeast Asia to the Philippines and Indonesia, and a bit later to India in 1968. From the time United Board returned to work in the Mainland in 1980, it has expanded its scope to working with an extensive network of over 80 higher education institutions in 15 Asian countries/areas.

Care for the needs and development of the local communities has always been core to the mission of the United Board's work in higher education. Rather than evangelism in the

\footnotetext{
* Corresponding author: wcwong@unitedboard.org
} 
narrow sense of converting everyone a Christian, United Board has adopted a broad theological framework of instilling Christian presence where it works in terms of witness in service. In many countries when the missionaries began their work, Christian presence was most vividly expressed in the trilogy of mission in preaching, teaching and healing/service through the establishment of a church, a school and a hospital side by side in the field. Service in terms of education and care of the community has thus been an integral part of the mission of Christian colleges and universities from set up. In the 1960s when servicelearning emerged in the United States as a conscious pedagogy for experiential education, United Board took it up as one of its core program support. It was not until 1999 however, more systematic advocacy for service-learning was launched by the Board. Care for the needs and development of the local communities has always been core to the mission of the United Board's work in higher education. Rather than evangelism in the narrow sense of converting everyone a Christian, United Board has adopted a broad theological framework of instilling Christian presence where it works in terms of witness in service. In many countries when the missionaries began their work, Christian presence was most vividly expressed in the trilogy of mission in preaching, teaching and healing/service through the establishment of a church, a school and a hospital side by side in the field. Service in terms of education and care of the community has thus been an integral part of the mission of Christian colleges and universities from set up. In the 1960s when service-learning emerged in the United States as a conscious pedagogy for experiential education, United Board took it up as one of its core program support. It was not until 1999 however, more systematic advocacy for service-learning was launched by the Board.

\section{United board's recent work in service-learning}

Since the early 1970s, community outreach was identified as one of the most important areas of work for the United Board. Between the years of 1970s to 1990s, the Board supported many projects in the colleges and universities that were designed to integrate instruction, research, and community involvement in the institutions. Not only that the Board intended to educate students to be aware of the needs in the community including poverty, social injustice and ecological and environmental problems, but also that community service must not be resulted in paternalism or dependency. The goal of community outreach by the universities must allow full participation of the people in the community for empowerment. From the beginning, United Board defined its community outreaching work to be "an integral part of a student's education, rather than 'charity' from a Christian university to the needy at its gates. It was seen not as a distraction to the learning process, but as an enrichment" [1].

In 1999, convinced of the promising results of service-learning as pedagogy, the United Board organized a Faculty Seminar on Service Learning with the International Partnership for Service Learning (IPSL) ${ }^{1}$ held at Trinity University of Asia (then Trinity College) in Manila. After some exchanges between United Board and IPSL for about a year, the United Board decided to appoint a William Fenn lecturer: Florence E. McCarthy ${ }^{2}$ in 2000 to help

\footnotetext{
${ }^{1}$ The partnership between the United Board and IPSL for the re-launching of service learning in higher education in Asia was probably made possible with Linda A. Chisholm, serving then both as the President of IPSL and a trustee of the United Board. Dr. Chisholm has been a veteran in higher education work including her presidency for the Association of Episcopal Colleges (AEC), 1987 to 2000, and being the founder and first general secretary of Colleges and Universities of the Anglican Communion (CUAC).

${ }^{2}$ Florence McCarthy was trained a sociologist and had taught at Cornell University and
} 
pave the road to more active work in the area. Her mandate was to help the colleges and universities in Asia develop proposals for the United Board's funding support. Because of McCarthy's efforts, service-learning projects started to take root in Taiwan, Thailand, India, Japan, Korea, Indonesia and the Philippines from 2001. After the first set up, McCarthy was funded again by the United Board to make return visits to the twelve institutional projects that she helped to build and to assist them with their implementation. As a result, firm foundation was laid in the institutions involved in these countries such as Fujen Catholic University in Taipei, Payap University in Chiangmai, Lady Daok College in Madurai, International Christian University in Tokyo, Yonsei University in Seoul, Petra Christian University in Surabaya and the Trinity University of Asia in Manila, which have all emerged as regional leaders in service-learning, having integrated it into undergraduate education as an essential component of teaching and learning [2].

As a result of the initial work, a regional network of institutions for service-learning began to take shape. The first Asian conference on service-learning supported by the United Board took place at International Christian University (ICU) in Tokyo in 2002. In the opening of the conference, Kano Yamamoto, Chair of the Organizing Committee and Chair of ICU's Division of International Studies marked the goal of the conference as "establishing ties among institutions of higher education and community agencies" because "the effects of linking these institutions into networks of exchange among students, faculty, administrators and community people should promise even more powerful outcomes" [3]. One of these successful outcomes was the establishment of Service Learning Asian Network (SLAN) ${ }^{3}$ by the participating institutions, again with the initial support of the United Board [4]. For coordination for regular institutional exchange, United Board established a Service-Learning Program Committee at the Tokyo conference who later met at the Board's Hong Kong office where a "Policy Guidelines for Service-Learning Program" was developed [5]. For the years that followed, the Board conducted a series of service-learning coordination workshops facilitating exchanges of lessons learnt from the various case studies among the participating institutions. In 2003, the first regional workshop kicked off at Hong Kong Baptist University, bringing about eighteen institutional representatives for examination and mutual learning from twelve service-learning programs. In 2005 the second workshop conducted with the focus on curriculum building was held at Chung Chi College of the Chinese University of Hong Kong. In 2006, the third coordination conference specifying the theme on evaluation strategies and program assessment was organized by the United Board in Hong Kong. In between these regional workshops, there were also national conferences organized in several countries around Asia including India, China and Korea in 2004, and Guizhou of China and Indonesia in 2006. During this period, United Board's staff and trustees including David Suh, Betty Abregana, Kano Yamamoto, Willi Toisuta and Shanti Manuel constituted a mobile team actively

Teachers College, Columbia. She has been involved in international service-learning in the United States since 1989 and has had extensive experience in educational and social development issues and programs. She is currently an Adjunct Associate Professor of the Centre for Educational Research at the University of Western Sydney, Australia.

${ }^{3}$ A brief reference is made on the introduction of SLAN on the website of Lingnan University which took up the coordination of the secretariat of SLAN since 2011, see https://www.ln.edu.hk/osl/network_SLAN.php (Accessed on 6 November 2017). As stated on the site, the purpose of SLAN is "to promote the common interests and networks of student exchanges, faculty research, curriculum development and program evaluation among colleges and universities interested in Service-Learning in Asia. SLAN members share ideas about the development of Service-Learning in the region and have united together to encourage cross-national collaborations." 
lecturing and promoting service-learning in the different institutions and events around Asia [6].

Over the years, numerous short and long term projects on service-learning have been supported by the United Board's grant programs. From 2002 to 2007, a total of 35 institutional projects on service-learning were granted. (See Figure 1) In the past $5 \mathrm{yr}$, campus-community partnership primarily taking the form of service-learning has been identified as one of the five main areas of programs of the United Board. The total number of service-learning projects over this period has amounted to a total of eighty, conducted by different institutions in ten Asian countries. These countries include Cambodia, China and Hong Kong, Indonesia, Myanmar, Philippines, Korea, Taiwan, Vietnam, with the number of projects topped by India.

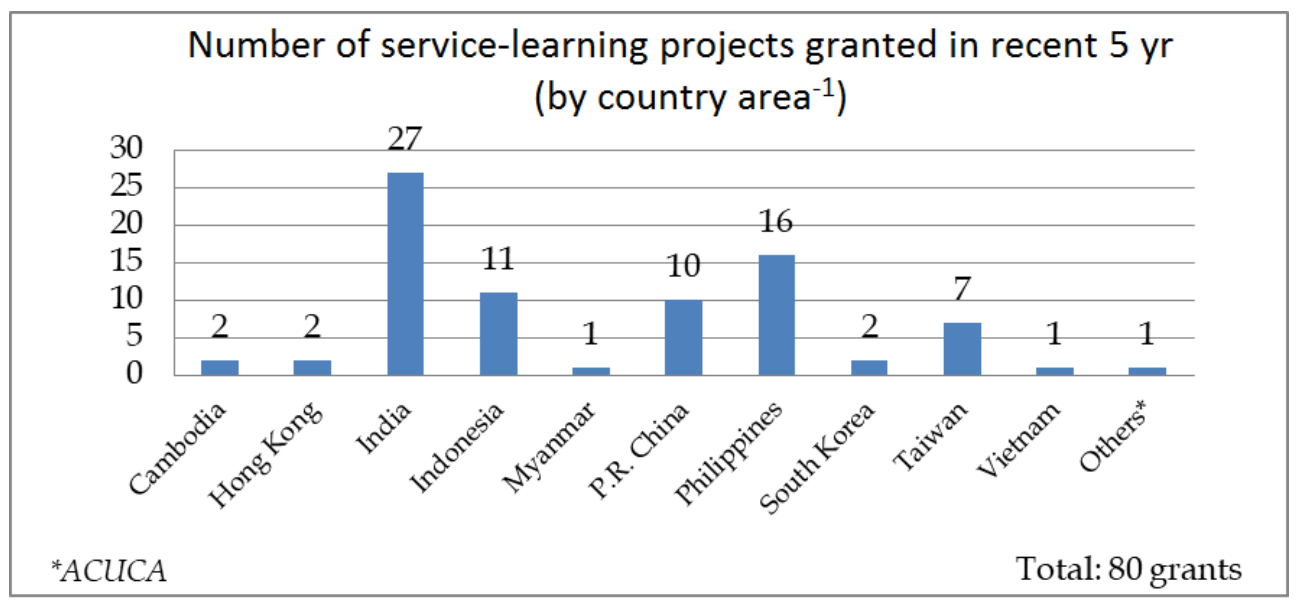

Fig. 1. Number of service-learning projects granted in the recent $5 \mathrm{yr}$.

In the most recent year of 2016 to 2017 alone, the United Board has supported 21 new projects leading to a total funding of about USD 150 000. Some examples of these community engaged projects include nurturing resilience in prospective teachers with students in poverty in Cambodia, training of students in collective bargaining practice for laborers in Nanjing, services to children of ethnic communities in Shaanxi of China, working with local government units and parent leaders of the riverine families for health and environment community-based education in the Philippines, field action in Irula settlements in Kancheepuram and the empowerment of the visually impaired students in India-just to name a few [7].
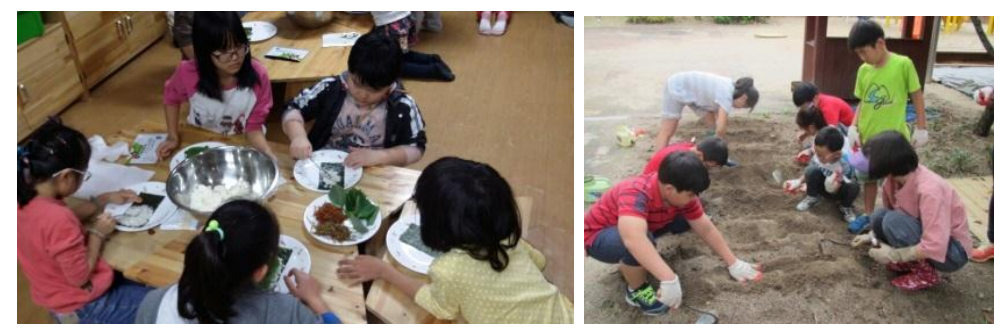

Fig. 2. Seoul Women's University on food justice with environmental education for children, Korea. 

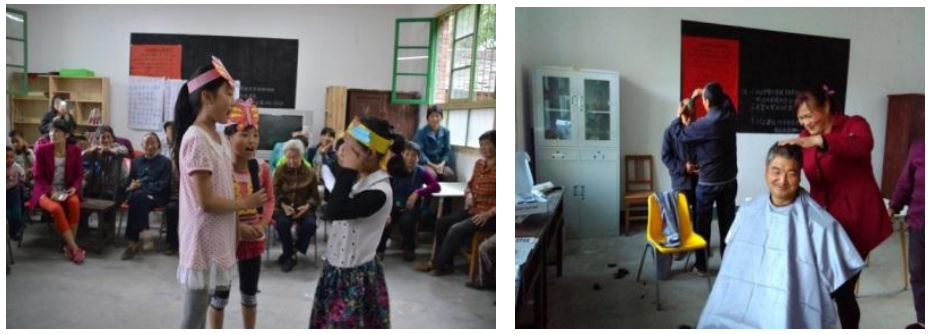

Fig. 3. Hong Kong Polytechnic University on participatory capacity building for social work educators in Shaanxi, China.

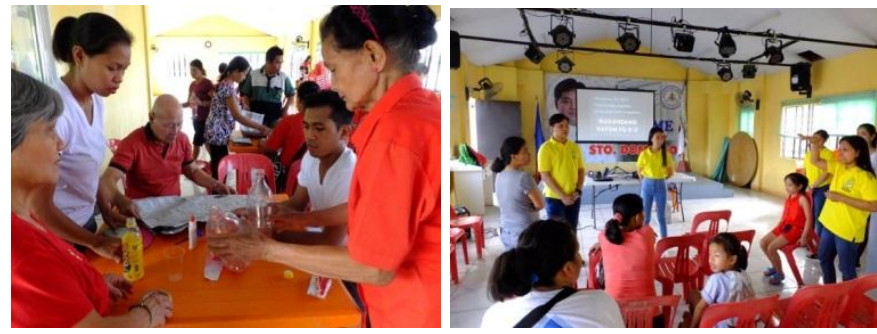

Fig. 4. Trinity University of Asia on Engaging Public and Private Partnership towards the promotion of health and people's well-being for environmental sustainability in Riverine Communities, Philippines.

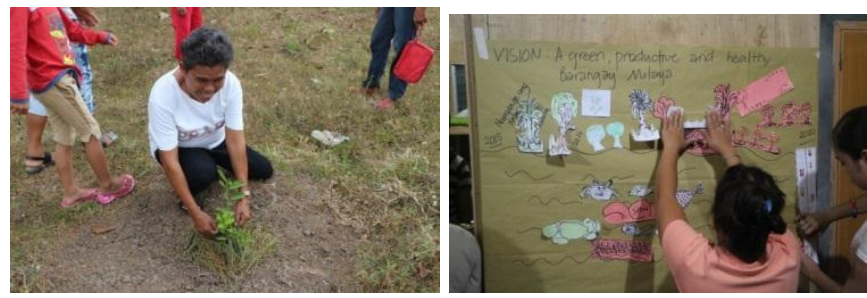

Fig. 5. Southern Christian College on trailblazing: pathways towards communities of change, India.

While there are many projects held by colleges and universities in the various local communities in Asia, in response to the catastrophic typhoon Yolanda in 2014 [8], the United Board organized for the first time the International Service Learning Program (ISLP) for the rebuilding of the much shattered coastal communities of the Philippines. Initiated by the United Board, a gathering of 120 staff and students from June 28 to 11 July, 2014 was called to take part in the project. Cohosted by Central Philippines University, University of St. La Salle and Silliman University and supported by Filamar Christian University and College of St. John Roxas, the project was also joined by South Christian College and Trinity University of Asia in the Philippines, Amity Foundation from China, Christ University from India, Seoul Women's University from Korea, Dagon University from Myanmar, and Soegijapranata Catholic University from Indonesia, a total of 12 institutions from six countries working side by side in ten remote villages of the Philippines for $2 \mathrm{wk}$ [9]. This project did not only bring about institutional leaders, faculty and students for concerted reconstruction efforts but also involved extensively community leaders, churches, local NGOs such as the YMCAs, and the municipal government who joined the local families in providing transportation and home stay for the different groups involved [10]. The 2 wk long activities organized covered a wide range of services including reconstruction of homes from building cement blocks and painting, clearing of trash, conducting seminars on family planning and reproductive rights, feeding and teaching 
children at the day care centers, etc. Feedback of the participants was not only about the knowledge they learnt about disaster and reconstruction but also about a life enrichment experience for faculty and students. Together the participants and the communities formed a strong bonding across countries, religions, education and urban-rural boundaries that extended beyond the program.
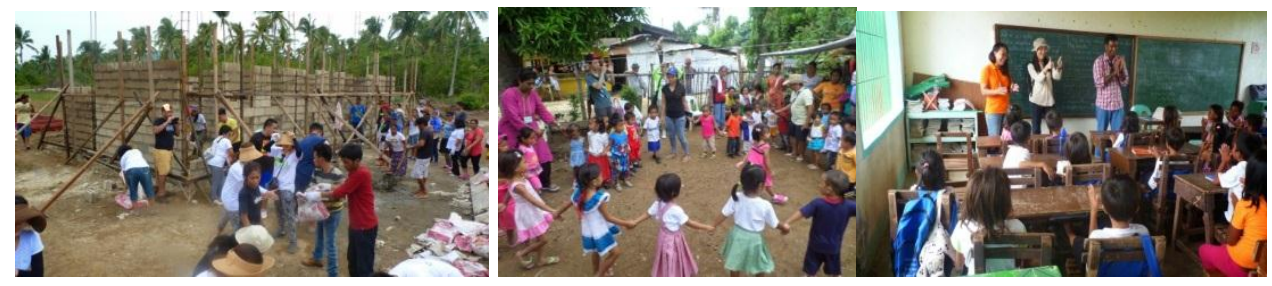

Fig. 5. International service learning program in Philippines.

\section{Growing together as service-learning actors}

In response to the movement to institutionalize service-learning in the American higher education, Dan W. Butin presents a critical picture of the otherwise. He argues that the mission and the impact of service-learning have been gravely overrated. Not only that it has remained on the peripheral of the academy and that those engaged in it are not taken seriously by their institutional leaders, but also more fundamentally, that its proclaimed mission to transform the academy, the community and society has largely failed. Sympathetic to the cause of service-learning, Butin reputed the trend to quantify its impact but proposed to "disciplining" service-learning to make it a fully integrated academic pursuit capable of self-critique and theorization [11]. While it is agreeable that all servicelearning advocates must be cautious of and that the impact of service-learning cannot be much quantified, Butin's pushing service-learning to disciplinize itself is just as futile. Not only that his example of women's/gender studies may not provide as optimistic a picture of disciplining a subject as he would expect, he has grossly underestimated the tension of theory and practice in any given subject related to the community and the controversies of setting up a cross-disciplinary program as such in any higher education institution that has been trapped in the race for ascending academic ranking ${ }^{4}$. With a stronger element of selfcritique and ongoing reflection, it is evident that we must appreciate the institutional weakness of service-learning as also its strength. Service-learning can be and should be engaging in efforts of improvement for different forms and contents learning, reviewing its contribution and blindness in a certain pedagogical and curriculum designs, but its essential contribution to affective education cannot be overlooked. In one of the early reports that McCarthy submitted to the United Board, she titled this essential contribution as "Educating the Heart." [12].

Testamonies from the service-learners have always been overwhelmingly touching. In one case, service with two Gawad Kalinga (GK) communities involved in the reconstruction of homes that consisted of carrying 300 hollow blocks to the site, sifting sand for mixing cememt, backfilling of two units with soil and stones, and painting the gutters. Reflections from the service-learners mentioned their learning about the physical challenges of the tasks required, but more importantly, their registering deeply the appreciation of people engaging in hard labor for a living. Working together with the

\footnotetext{
${ }^{4}$ Academic ranking has become the dominant international assessment tool for higher education for the last decade. Unfortunately, its assessment is primarily subject knowledge and research based.
} 
villagers also made them realize the strength and courage of the people in the community and the community's ability to bounce back from the devastation of a disaster. The reality of poverty or the aftermath of a disaster, the often physically demanding manuel labor, and the very simple and basic living conditions of the sites of service would inevitably create some deep impressions in the service-learners in the field. Nevertheless, the greatest lessons they would learn are usually not how difficult lives could be in most of the sites they visit, but how people can demonstrate a spirit of hope despite the difficulties. That happiness does not equal material affluency can deeply change the service-learners perception of the meaning of life. A participant of IPLS recalled how helping others has turned out to be an opportunity for him to experience how working through difficulties together which allows him to feel "something larger and stronger than oneself." In serving and living with other students, the community workers, and the villagers the participants experienced a process of growing together and becoming stronger as a team. They did not only learn about the idea of but saw in practice how mutual acceptance, continuous adjustments and adaptability are necessary for them to acquire the courage to crossing unfamiliar borders. Another participant reflected that diversity in personality was not only not a threat but a richness when all may work together with a sense of unity toward "one goal, one vision." In the field rather than the classroom, many service-learning participants once and again testified how effective it has been to learn leadership by example, understand by doing, and that everyone is needed, no matter how seemingly strong or weak one may look, in order to achieve the task. In a subtle way, the striking message of IPLS has planted in its participants a deepened knowledge of disaster response intellectually, the meaning of community resilience spiritually, and a heartened reflection on the social responsibility of Asian universities today ethically.

Sometimes the educational purpose of servive-learning for students is recognized beyond the cost paid. In the reflection of a faculty member of Soochow University in mainland China, one of the service-learning actors, plainly admits that "nobody in the faculty would like to do it, they were actually surprised that I would be willing to spend the time. ... but I saw it as my mission, ... the experience working with the students/teachers/

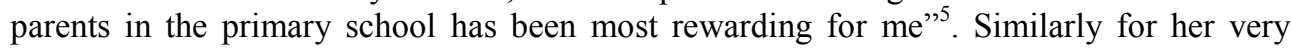
committed students who spent their whole summer in reading, researching, and developing with her the various kinds of teaching aids for the primary students they took care of. Her service-learning project targeted the students with learning disabilities, through the special training program she developed with her research students, she was most encouraged to see not only the improvement of the students of learning disabilities in the process but also that of her own students. "Our project not only helps students make progress in building knowledge, but it also makes them conscious of serving society. That is an important outcome for college students" [13]. In another case, an English student service-learner in Nanjing learnt something dearly from the field. Rather than studying English in the classroom she joined her teacher and classmates to run reading groups at the children's library in the city. In her student feedback she recalled, "I discovered English a new. ...I thought I know English by its delicate vocabularies and phrases, but I was totally ignorant of its colloquial usage, daily expressions... the children know more about the language of the picture books than me... ." Despite the many additional hours they spent in the project, another student echoed by saying how she learnt the lesson of reciprocity by heart, reflecting, "The relationship between myself and the children is never that of serving and being served. I believe that we are equal. ...Until now, my service is not about helping others, but an act of mutual sharing." Despite the extra work required of him, it is the Pharmacy student service-learner from Hong Kong who provided one of the most profound

\footnotetext{
${ }^{5}$ Interview in October 2016.
} 
reflections on the reciprocity of give and take in the experience. In his student feedback he wrote, "I always heard former participants reporting on their experience of many more gains than loss in the service they took part in. In the past I would only nod without really understanding - until I had my service-learning trip in Myanmar. ... Now I would conclude my trip with three words: sedimentation, internalization and transmission-there is a feeling of love settling deep down in my heart, internalized as an organic part of me, and am translating into action and allowing me to pass it on" [10].

The transformatory effect of the "service" cannot be underestimated. Service-learning is a practice that is meant to be provocative, critical and disruptive for self-examination and let be changed [14]. If self-critique and examination are traditionally assigned to the cognitive side of learning, provocative and let be changed necessarily involved also the affective dimension of learning. In fact, many past studies have shown that outcomes of service-learning are at its strongest on affective learning by which service-learners acquire "self-confidence, social responsibility, civic-mindedness, self-esteem, and personal efficacy, just to name a few" [15]. In the case of a service-learning actor, a parent representative from Barangay St. Domingo, she recalled the experience with the faculty and students who came to her village to share with them knowledge about environmental health. Rather than hearing the ideas from a distance, she was touched by the their presence and their sincerity in caring about the village's environment. She felt deeply grateful because together with the villagers they began to see "the importance of preserving our nature is interrelated with health and the well-being of individuals, especially those of the next generation" [10]. The experience changed the old belief of the villagers toward environment health and economic development; it also broke the wall between knowledge acquired by the students in the institutions and everyday practices in the community. With the faculty and students' enthusiastic participation in the teaching and living with the villagers throughout the service-learning activities, both the students and the community crossed boundaries between serving and the served, and self and the other. In fact, how, when and what service learners may reasonably expect and be prepared for when placed into situations highly alienated from their own is the most demanding art of learning in education. Most importantly, what is demonstrated is how learning in both the students and the community took place both cognitively and affectively. This analysis does not mean to dichotomize learning into two dimensions; rather, it intends to draw attention to the often undermined aspect of affective education ${ }^{6}$. Sometimes better other times worse, the process of campus and community partnership is no doubt a collective experience of fostering education and change in both students and the local community cognitively and affectively [16].

\section{A paradigm of border crossing learning}

Despite Butin's sound argument of the need to align service-learning with critical academic inquiry, the importance of "educating the heart" is often overlooked by higher education. The very challenge of the development of higher education today is actually not so much about subject knowledge but character formation and spiritual nurturance. The next generation will no doubt face all kinds of new challenges that are unanticipated by their teachers today. In the United States, about $47 \%$ of the existing jobs is predicted to be taken over by technology and artificial intelligence in roughly 20 yr. Ironically, surveys show that

\footnotetext{
${ }^{6}$ Kezar and Rhoads rightly point out that John Dewey's education philosophy, of which the conception of service-learning is primarily based, clearly rejects the dualism of cognitive and affective learning. Kezar and Rhoads, "The Dynamic Tensions of Service Learning," 164.
} 
the jobs that will not be easily replaced are those requiring soft skills such as creativity and social skills [17]. The prevalent model of compartmentalization of knowledge and commercialization of education that aims at utilitarian purposes will not be able to meet these changes. Rather, what will be in high demand are education that will contribute to students' character formation and the skills of problem solving, knowledge application, ethical reasoning, adaptability, and interpersonal skills that would prepare them to face the ever-evolving world. Not only that well designed and reflective service-learning in higher education is designed to do exactly that [18], but evidences also show that service-learning contributes to students' greater capacity to accept cultural differences, and taking serious their responsibility to the community and their roles as citizens in a democratic society [15].

One may say that the one most pervasive hidden curriculum in campus-community partnership is the component of border crossing. Transformation of the service learners takes place because of the fact that all service-learning activities must be border crossing; a service learner can never stay in the same "place" from which she or he is originated, be it physically or experientially; some kind of crossings would definitely happen from either side of the service. Interestingly, one of Butin's main criticisms is directed to servicelearning's claim in "fostering 'border-crossing' across categories of race, ethnicity, class, (im)migrant status, language, and (dis)ability" [11]. He questioned the premise of border crossing for service-learners to people of disprivileged or minority background which neglects the reality that many of these service-learners are actually coming from these background. He may be right about the increasingly diverse body of students in higher education these days, but it does not mean that students of multicultural background would automatically lead to their capability to reach out to others on campus. In 2000, Muslim vigilantes attacked and burned down the entire campus of Doulos Seminary, wounded many students and even killed a few. On August 30, 2016, Florence Sihombing, a graduate student at Universitas Gadjah Mada in Yogyakarta, was arrested on criminal defamation charges after she called the city "poor, stupid and uncultured" on a social media network [19]. Only this last Spring, religious intolerance took the life of a young Pakistani student at Abdul Wali Khan University in the northern city of Mardan [20], and a mob attack on African students in New Delhi shocked the nation whose higher education has been pushing toward greater extent of internationalization [21]. Against the background of a post-truth world where appeals to personal belief are taken more serious than objective facts, freeing academic campuses from the grip of politics and ideology by keep people of difference in touch before conflicts becomes all the more important. In such context, encouragement for faculty and students to cross borders to see people different from themselves face to face, working and living with them as co-workers, neighbors, and friends in everyday life is crucial in planting the seeds for peace.

Rather than radically transforming the academy, community and society as some idealist advocates of service-learning would want to see, it is important to highlight that affective education through border crossing is in fact what underlines the primary values of service-learning activities. As well testified by the service-learning actors above, the best way to breaking down the seemingly tough barriers of religion, race, ethnicity, class, language, migrant status and differently abilities is the nurturance of friendship across the different sides. Through making friends, the service-learning actors learnt from each other not only through the mind but by touching one another's heart. Paul Riceour, a French philosopher, wrote an important book on "oneself as another" dissolving the binary of self and other into an integral whole. He argues that the self that one becomes or is ever becoming is profoundly bound up with the other by both sharing of sameness and entangling with difference. In other words, there is no self without the other in me [22]. Taking to task the psychoanalytical insight of everyone has a stranger inside to work with, Julia Kristeva, a native Bulgarian philosopher in France, also explains how an illusory 
construction of a static identity of a subject can only be shaken up through one's confrontation with the stranger inside. In order to cope with the deep down internal conflicts within oneself, people used to reject the difference of the Other for the imagined assurance of stability. "Confronting the foreigner whom I reject and with whom at the same time I identify, I lose my boundaries, I no longer have container..." [23]. In other words, the direct encounter between self and the stranger, whether internal or external, is the only possibility for change and growth.

When both society and the employers are pressing for young future leaders to be equipped with soft skills, the way of doing higher education as usual are being challenged. Inherited from the great philosophical and theological schools of the premodern times, the model of elitist education addressed not only the few but primarily for the training of the mind. With industralization in the eighteenth century and increasing massification of education in the twentieth century, education took a quick turn toward professionalization and vocational development. Despite the rhetorical emphasis most higher education systems have placed on scientific innovation, the majority only focus on the massive production of technological laborers. Education for the skills of problem solving skills, analytical power, creativity and interpersonal relations cannot be achieved by either one of these approaches but both. Unless a combination of the philosophical mind and the scientific inquisition is equally embraced, our college and university students would not be able to work through the problems facing them in the near and long future.

If it is seriously conducted, service-learning programs provide one of the best platforms for the comprehension of complexity. Service-learning opens up multiple opportunities for continous questioning, reflections on challenges and insights which together constitute "high-quality" reflection. In working with the communities, it allows for a genuine engagement with and understanding of how communities function and the means of strengthening them on the one hand, and engages the complexities, frustrations, and opportunities for long term commitment to and support of communities on the other.

With careful guidance by dedicated educators, analysis can be deepened and integrated which would lead to the better development of skills in teamwork, communication and problem-solving. Reflection that is open, accepting multiple perspectives, and contextualized in the community would be more often conducive to reasoned analysis and reflective judgment [18]. The adoption of service-learning institutionally will also make a strong statement about the higher education's role for public accountability, which itself may lend solid support to cultivating a cutlure of care and responsibility for accepting difference in the increasing pluralistic campuses.

\section{Conclusion: Advancing different levels of networks}

The need for networking in order to sustain and advance service-learing is apparent. There are however three levels of networks for service-learning actors. They are the institutional, national and international. First, on the institutional level, service-learning provides a very good venue for interdisciplinary collaboration across departments and faculties. Some departments who can more easily find common subject are actively engaging in such interdepartmental projects. For example in one project recently funded by the United Board, faculty and students of Nutrition Science and Gerontology of a Chinese university were brought together for a program caring for the health and quality of life for the elderly. Externally, service-learning projects are known to provide valuable opportunities for the academy, primarily responsible for the production of knowledge, to link up with the community, supposed to be the primary benefactors of knowledge advancement, with extension to partnering with the non-governmental organizations and the local government for the advocacy and implementation of appropriate measures to bring about change. This 
is the case of another United Board funded campus-community project in Indonesia in which a team of architecture faculty and students, in partnership with the local chapter of Habitat for Humanities, committed to a multiyear project to improve the living condition of the poor neighborhood. Their programs have been so successful that the local government decided to work with them for the improvement of the living conditions for people in their city. The successful networking of the four main social actors: the academy, community, NGOs and the government can be teamed up to make real change to the local community in the long run.

Second, on the national level, rather than seeing one another as competitors for resources and ranking, service-learning activities that target issues of the local society will serve as a convenient vehicle for inter-institutional collaborative projects in a province, region or district. A project of a university in the Philippines that originally focuses on the development of resilient persons in the face of disaster has extended their expertise to train the faculty of another Philippine institution that is trapped in ethnic and religious rivalry last year. Together they aim to form a team of trainers who may continue to help address the questions of violence, disaster and their impact on the community aftermath. The needs of the communities pull the two faculties together and build stronger teams of talents and strengths across institutions for the better.

Lastly, the international level of network would involve collaboration with regional or global service-learning bodies which are organized around Asia and the world. While higher education in general takes internationalization increasingly important as the way forward, the quality and form of internationalization incline to be quite monolithic, focusing largely on the recruitment of faculty and students overseas but short of the vision and efforts to conduct in-depth intercultural exchange among local and overseas faculty and students, and almost nothing in engaging them in understanding one another with the very diverse cultures they brought with them. On the contrary, International service-learning, as the one the United Board organized in 2014 or some similar programs organized by Asian universities such as that of Petra Christian University and International Christian University, advances the most profound way the "global" mission of a university. An Associate Provost of an American university once articulated his true goal of internationalization by saying, "We are trying to connect the local to the global and to focus on how to help students engage in sustainable practices wherever they end up professionally." In short, internationalization should have an aim and it is about equipping students' capacities to be responsible members of the global community. A faculty of Silliman University testifies that it is through his learning in an international setting, "studying... abroad, in general - where you adjust to a new environment outside your comfort zone, facilitates a different kind of maturity and builds a stronger sense of being a Filipino." In a globalizing world, young people must be prepared to living in a world that is radically different from the present, a world wide-open, in order to understand others as well as their own selves. As an educator today, it is our job to prepare them not only for the knowledge that has too quickly evolved but the adaptability and openness to face the world of uncertainty and change. The "Global village" that has once been championed as promises of the future has produced increasing instability in every nation not only in terms of markets but about the public good. The constant flow of people, the multicultural flow of travelers, and instant companionship have resulted in a faceless crowd. The universities who try by every means to be internationalized must also address the question of why and what imperative behind. Internationalization with campus-community engagement that leads to a better understanding of students and the wider world can serve an essential university function.

One of McCarthy's visions as the William Fenn Lecturer in the milleninium year was to cultivate "an environment of learning communities, in which tertiary institutions work 
interactively and in partnership with community agencies in creating active learning environments for students, faculty, and community members" [2]. To advance this vision, she advocates network building as an essential vehicle for both fellowship and support among Asian institutions. There are many reasons for the need to create networks among academic institutions interested in service-learning:

First, networks encourage the exchnge of information among participants such as faculty and administrators that helps solve problems; they are a source of support, new ideas and information, and ideally, become the basis for the exchange of students. Second, networks bring the participating institutions together, creating shared interests and feelings of mutuality that contribute to stronger ties among Asian coutnries. Third, networks reinforce the importance of service learning and add their own encouragement to reluctant administrators to reconsider their support for servicve learning [2].

The series of coordination workshop for service-learning in the interested institutions in Asia and the subsequent set up of SLAN for regional networking were responses of the United Board to advancing service-learning networks. SLAN was particularly established to promote and support teaching and research in relation to service learning. Together the various levels of networking aim to explore the scholarship of engagement, promote civic education, and reaffirm the role of colleges and universities as citizens. For advocates for higher education's strengthened ties to society, it is important to call for a return of education to "the basics" that would re-articulate the meaning of education today. The different levels of networking of service-learning actors may then consolidate our capacity to respond accordingly for "even more powerful outcomes" [3]. It may serve as an extended alternative platform for international cooperation for the sharing of resources and sustainability and the establishment of institutional recognition through consolidated action research and policy advocacy. Building on many enduring community partnerships and engagement with multifaceted communities, it is time to further consolidate the experience and efforts made by the service-learning actors across institutions and regions to contribute more effectively to advanced documentation, systematic reflection and theorization the subject for long term sustainable strategizing. In order to do this, service-learning must be institutionalize to bring coherence and direction to the college and university. This would include placing service learning not as a peripheral program but at the center of mission; supporting it at all levels including: presidents, advisory boards, core faculty, multiple aspects of campus programming through either scholarships, general education courses and admissions policy, etc. For further support of service-learning through the provision of mini-grants for course developments, faculty workshops, campus seminars, and participation in training and conferences, they have been deeply rooted in the mission of the United Board and will stay core to our programs for the years to come.

\section{References}

1. P.T. Lauby. Sailing on winds of change: two decades in the life of the United Board for Christian higher education in Asia 1969-1990. New York: United Board for Christian Higher Education in Asia (1996). pp. 58-59 https://www.amazon.com/Sailing-WindsChange-Christian-Education/dp/096469431X

2. F.E. McCarthy. Background paper: service learning and the construction of networks and curricula. Service Learning in Asia: Creating Networks and Curricula in Higher Education (Tokyo, Japan, 2002). pp. 22-24.

3. K. Yamamoto. Introduction. Service Learning in Asia: Creating Networks and Curricula in Higher Education (Tokyo, Japan, 2002). 
4. Lingnan University. Service-learning Asia network (SLAN) [Online] from https://www.ln.edu.hk/osl/network_SLAN.php (2016). [Accessed on 6 November 2017].

5. United Board for Christian Higher Education in Asia. Policy guidelines for servicelearning program. [Internal document].

6. United Board for Christian Higher Education in Asia. Chronology of United Board's involvement in service-learning. [Internal document].

7. United Board for Christian Higher Education in Asia. Program report. Board of Trustees Meeting Briefing Book (May 2017). [Internal document].

8. Philippines Associated Press. One of world's strongest typhoons lashes Philippines [Online] from http://newsinfo.inquirer.net/523635/yolanda-one-of-worlds-strongesttyphoons-blasts-philippines (2013). [Accessed on 6 November 2017].

9. G. Shive. Site visit report and reflection program for the international service learning project, Visayas, Philippines (June 26 to July 12, 2014). United Board for Christian Higher Education in Asia, unpublished. [Internal document]

10. H. Antone. Report on the international service learning program, Panay and Negros Islands, Philippines (June 28 to July 11, 2014). United Board for Christian Higher Education in Asia. [Internal document]

11. D.W. Butin. The Review of Higher Education, 29, 4: 473-498 (2006). http://citeseerx.ist.psu.edu/viewdoc/download?doi=10.1.1.392.9924\&rep=rep1\&type= pdf.

12. F.E. McCarthy. Educating the heart: service learning and Asian institutions of higher education. Report prepared for the United Board for Christian Higher Education in Asia and the International Partnership for Service Learning. New York (2001). [Internal document].

13. I-J. Chen. Horizons, (June 2017): 4 (2017).

14. Higher Education Quality Committee (HEQC). A theoretical and conceptual framework for service-learning. In: Service-learning in the curriculum: a resource for higher education institutions, higher education quality committee (HEQC) (Eds). Pretoria, South Africa: The Council on Higher Education (2006). pp. 13-28. http://www.che.ac.za/media_and_publications/research/service-learning-curriculumresource-higher-education-institutions

15. A. Kezar, R.A. Rhoads. The Journal of Higher Education, 72, 2: 148-171 (2001). https://www.jstor.org/stable/2649320?seq=1\#page_scan_tab_contents

16. B. Jacoby. Service-learning in today's higher education. In: Service-learning in higher education: concepts and practices. B. Jacoby and Associates (Eds). San Francisco:

Jossey-Bass (1996). p. 3-26. https://www.wiley.com/enus/Service+Learning + in + Higher+Education $\% 3 \mathrm{~A}+$ Concepts + and + Practices-p$\underline{9780787902919}$

17. C.B. Frey, M.A. Osbourne. The future of employment: how susceptible are jobs to computerization [Online] from http://www.oxfordmartin.ox.ac.uk/publications/view/1314 (2013). [Accessed on 24 October 2017].

18. Z. Hutter, L. Ahmed, J. Plaut. Reflection in higher education service-learning [Online] from http://www.usf.edu/engagement/documents/reflection-in-he-sl-fs-short-sept08.pdf (2008). [Accessed on 30 October 2017]. 
19. U.S. Commission on International Religious Freedom. Annual report 2017 [Online] from http://www.uscirf.gov/sites/default/files/2017.USCIRFAnnualReport.pdf (2017). [Accessed on 30 October 2017].

20. A.A. Khan. University officials linked to lynching of student [Online] from http://www.universityworldnews.com/article.php?story=20170421134357622\&query= mardan (2017). [Accessed on 30 October 2017].

21. Y. Sharma. Uproar over violent mob attack on African students [Online] from http://www.universityworldnews.com/article.php?story=20170330131144670 (2017). [Accessed on 30 October 2017].

22. P. Ricoeur. Oneself as another. Translated by K. Blamey. Chicago: University of Chicago Press (1992).

https://books.google.co.id/books/about/Oneself_as_Another.html?id=uCZSOYcB_CIC \&redir esc $=\mathrm{y}$

23. J. Kristeva. Strangers to ourselves. Translated by L.S. Roudiez. New York: Columbia University Press (1991). p. 187. https://cup.columbia.edu/book/strangers-tofourselves/9780231071574 